Special issue of the 2nd International Conference on Computational and Experimental Science and Engineering (ICCESEN 2015)

\title{
Solar Array System Layout Optimization for Reducing Partial Shading Effect
}

\author{
B. KiriŞ̧,*, O. BingÖL ${ }^{b}$, R. ŞEnOL ${ }^{c}$ And A. AltintaŞ ${ }^{d}$ \\ ${ }^{a}$ Department of Electronic Computer Education, Suleyman Demirel University, 32200 Isparta, Turkey \\ ${ }^{b}$ Faculty of Technology Electrical and Electronics Engineering, Suleyman Demirel University, 32200 Isparta, Turkey \\ ${ }^{c}$ Faculty of Technology, Department of Mechatronics Engineering, Suleyman Demirel University, \\ 32200 Isparta, Turkey \\ ${ }^{d}$ Simav Technology Faculty, Department of Electrical and Electronics Engineering, Dumlupinar University, \\ 43500 Kütahya, Turkey \\ Solar cells are photovoltaic devices that convert sun energy directly into the electrical energy. Solar panel is \\ composed of multiple solar cells that are combined together. Depending on the power demand, solar panels are \\ connected to each other in series or parallel. Thus, electrical energy from the solar array systems is created to meet \\ the needs. Solar panels are used on roof and wall systems in buildings and power plants. In solar array design, \\ radiance, temperature, shading, surface angle and effect of series-parallel connection, which are factors affecting \\ the operation of solar panels, should be considered. Shading significantly reduces the efficiency of a solar array \\ system. Shading can occur entirely or partially due to dynamic or static obstacles. The effect of shading varies by \\ location at which the solar panel is formed. In this work, design and optimization of solar arrays, positioned over \\ a large area, having different time constant shading effects, was performed in order to minimize shading effect.
}

DOI: 10.12693/APhysPolA.130.55

PACS/topics: 88.40.H-

\section{Introduction}

The energy needed for technology age is the most important topic. With the developing technology, the rapid increase of world population causes an increase of energy consumption. Because of having the negative effects of new kinds of energy to the human health, using the oldfashioned energy production methods and depleting of the energy sources, research of new and renewable energy sources has become more common. Obviously the Sun is the most natural energy source, having both, the least damage to the nature and being easily available for everyone. For the reason of our country's geographical location, we are luckier than most of other countries for having sun energy. According to the research of EIE (Electrical Works Management Studies): the average of the total annual solar time in Turkey is: 2640 hours, the average of the total radiance intensity in Turkey is: $1311 \mathrm{~kW} / \mathrm{m}^{2}[1,2]$.

Solar cells are the photovoltatic (PV) devices converting the Sun energy directly into the electrical energy. The current and voltage provided by the smallest structure unit of PV systems are very low. To get a usable energy, a PV panel must consist of a lot of solar cells connected in series or in parallel to each other. Panels can also be connected in series or in parallel with others. By connecting the panels serially, the voltage range can be increased; and by connecting the panels in parallel,

*corresponding author; e-mail: berkaykiris@gmail.com the current capacity can be increased as well. PV panels constitute the PV array by serial or parallel connections; and PV array in question can be named "solar PV array" $[3,4]$.

The electrical energy produced by PV panels can be affected by the radiance, the temperature, the angle of the surface and by shading. Even if the PV panels are identical, each PV panel still can produce different current and voltage. The PV panel with lower power produces lower current at serial connections, and lower voltage at parallel connections. Thus, output of the PV system is affected negatively. Each PV panel's current and voltage difference have to be taken into account at suitable circuit design for solar arrays [5, 6].

A study [4], related to shading effect of PV panels, has determined the optimal connection model at different conditions of temperature and radiation. Another study has examined the power production for different PV panel connection types by using the PSO algorithm on MATLAB platform [7]. Study [8] investigates the effect of mismatch losses of PV panel array located on the large area by using the Sudoku method.

In this study, different PV panel array connections, depending on the selected inverter types were investigated and visualized using $\mathrm{C} \#$ programming language. The PV panel replacement in the solar array and the optimization of circuit design is achieved using genetic algorithm. The parameters (radiance, temperature, angle of surface and partial shading) affecting the PV panel's output are included in the PV system to get more efficient results. 


\section{Modeling of photovoltaic system}

\subsection{PV cell model}

The most common model used to predict energy production in photovoltaic cell modelling is the single diode circuit model, represented in Fig. 1 [9]. Normally, the output of photovoltaic systems corresponds directly to solar irradiance and temperature, so obtaining the maximum power output should involve the most recent values of these factors [10].

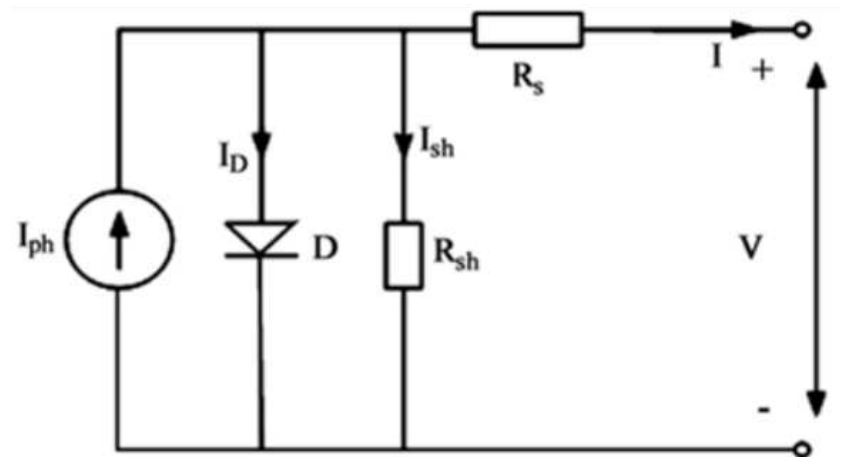

Fig. 1. Diode equivalent circuit for PV cell.

The mathematical model of PV cell also depends on the short circuit current $I_{\mathrm{sc}}$ and the open circuit voltage $V_{\text {oc }}$, which can be obtained from the cell manufacturer's data sheet.

This model includes a current source $I_{\mathrm{PH}}$, a diode and a series resistance $R$. Current source parameters depend on solar radiation and cell temperature; the relevant parameter of the diode is the inverse saturation current $I_{0}$, depending mainly on the operating temperature; the series resistance $R$ and shunt resistance $R_{\text {sh }}$ represent resistive losses. The current-voltage relationship of a photovoltaic cell is given by:

$$
I=I_{\mathrm{ph}}-I_{0}\left(\exp \left(\frac{V+R_{\mathrm{s}} I}{A}\right)-1\right)-\frac{V+R_{\mathrm{s}} I}{R_{\mathrm{sh}}},
$$

where $I_{\mathrm{ph}}$ is the photocurrent, $I_{0}$ is the diode saturation current, $A=n \frac{k T}{q}$ is modified ideality factor, $n$ the diode ideality factor, $k$ is the Boltzmann constant $\left(1.381 \times 10^{-23} \mathrm{~J} / \mathrm{K}\right), q$ is the electronic charge $\left(1.602 \times 10^{-19} \mathrm{C}\right), T$ is the cell temperature, $V_{T}$ is the thermal voltage $V_{T}=\frac{k T}{q}, R_{\mathrm{S}}$ is the series resistance and $R_{s h}$ is the shunt resistance [9].

$\mathrm{PV}$ module and mathematical translation equations given below.

$$
\begin{aligned}
I_{\text {new }} & =I_{\text {ref }} \\
& +\left[\alpha\left(\frac{G}{G_{\text {ref }}}\right)\left(T_{\mathrm{c}}-T_{\text {cref }}\right)+\left(\frac{G}{G_{\text {ref }}}-1\right) I_{\mathrm{sc}}\right], \\
\Delta I= & {\left[\alpha\left(\frac{G}{G_{\text {ref }}}\right)\left(T_{\mathrm{c}}-T_{\text {cref }}\right)+\left(\frac{G}{G_{\text {ref }}}-1\right) I_{\mathrm{sc}}\right], } \\
V_{\text {new }} & =-\beta\left(T_{\mathrm{c}}-T_{\text {cref }}\right)-R_{\mathrm{s}} \Delta I+V_{\text {ref }}
\end{aligned}
$$

where $I_{\text {new }}$ and $V_{\text {new }}$ are the measured current and voltage respectively, $G_{\text {ref }}$ and $G$ are the reference and measured irradiances, $\alpha$ is the temperature coefficient of the short circuit current, $T_{\text {cref }}$ and $T_{c}$ are the reference and measured temperatures, $\beta$ is the temperature coefficient of the module voltage.

\subsection{Solar $P V$ array parameters}

As with the connection of cells to form panels, a number of panels can be connected in series to increase the output voltage or in parallel to increase the output current or in a combination of the two [11]. The optimum configuration depends on the current and voltage requirements of the load. Placement of matching interconnected panels, in respect of their outputs, can maximize the efficiency of the array.

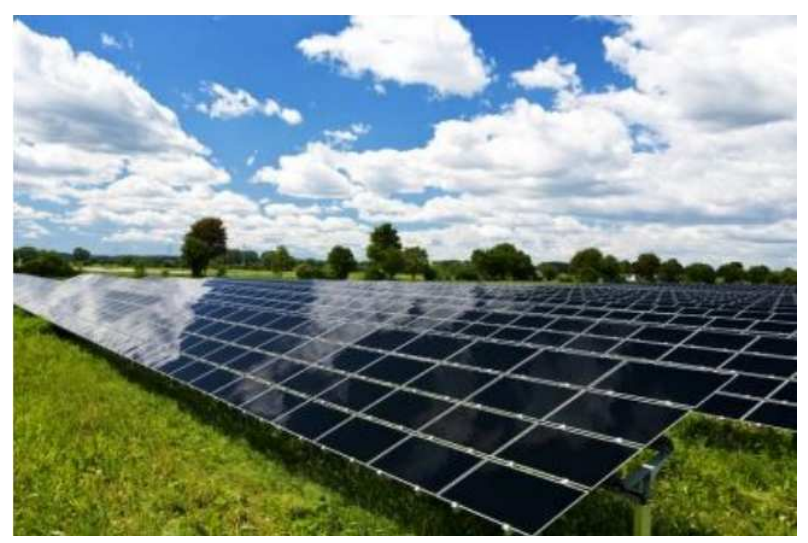

Fig. 2. Shaded solar array.

In the PV power generation system, multiple PV panels are generally connected in series or in parallel in order to obtain sufficient DC voltage [11]. The output power of a PV array decreases considerably, when current-voltage (I-V) curves of solar cells are not identical due to soiling, non-uniform irradiation and temperature variations, cell damaging, partial shading, etc. [12]. In wide areas with constant gradient, if identical PV panels are used, the most important factor for differences between powers of $\mathrm{PV}$ panels is shading. This situation is represented in Fig. 2. If a suitable connection method is used in the shady area, power loss of the system will decrease [7]. The basic reason for optimization process is decreasing losses in generated power.

\section{Overview of genetic algorithm optimization}

Genetic algorithm is an adaptive probabilistic search algorithm for global optimization which simulates biological genetic evolution in Darwin's theory [13]. Genetic algorithm has the capability to generate new design solutions from a population of existing solutions, and to discard the solutions which have an inferior performance or fitness [14]. Flow chart of genetic algorithm is given in Scheme 1. 


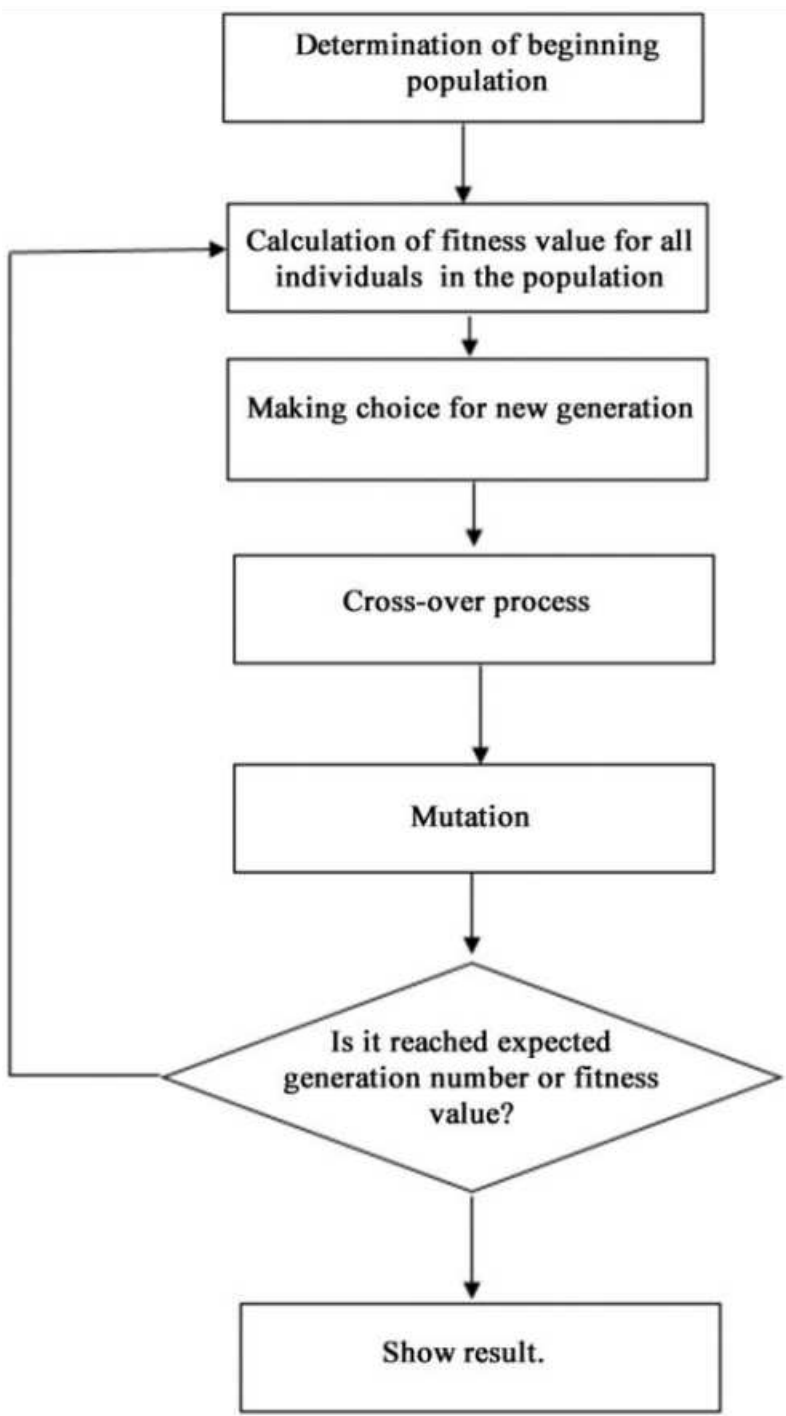

Scheme 1: Flow chart of genetic algorithm

Population is a community of individuals in genetic algorithm. Each individual is a possible solution of problem. Individuals occur from combinations of genes. Genes are shown as a holder of characteristics information. The genetic algorithm begins to hunt from the randomly generated initial population; goes through the operations of selection, crossover and mutation operators, and then generates a new generation of population [15]. Crossover operator and mutation operator are greatly crucial, and the crossover operator plays a core role in the genetic algorithm. Each individual in the population represents a solution to solve optimization problem. As a rule, applying the fitness value to measure each individual, a certain number of outstanding individuals are selected from the previous generation according to the fitness value, through crossover and mutation operations to produce a new generation of population. So, after a number of genetic iterations, the genetic algorithm converges to the best individual; it is the optimal solution or suboptimal solution for the solved problem [15].

\section{System design and implementation}

\subsection{Software design}

The simulation program is written in $\mathrm{C} \#$ programming language, using MSSQL database program. In software, all inputs for parameters of PV panel power are available.

Specifications of $\mathrm{PV}$ panels and inverters determined from the manufacturer's datasheets are entered into the simulation program. Real meteorological measurement results obtained from the area are also supplied to the program. By entering the area characteristics and selection of PV panels and inverter, the simulation program will be started.

Optimization process based on genetic algorithm has considered each PV panel as a gene, and solar PV array as an individual. The information of power production determines the specification of genes according to the location and shading situation. The individuals are created by the connection of PV panels in series or in parallel. A sample individual includes solar array circuit designs of PV panels. This solar array circuit design of PV panels is the initial population of the optimization process. The power of each solar array is obtained by a fitness function. The best PV panel array designs are created with mutation and cross-over genetic operators. These steps are repeated many times to obtain new population for determining the high power of PV panel array design.

\subsection{Illustration}

The location area of $1000 \times 600 \mathrm{~cm}^{2}$ in Isparta is selected for implementation. It is considered to contain Uni Solar US-64 PV panels oriented at $33^{\circ}$ tilting angle for a day in May. Meteorological data are shown in Table I for that day. The system is designed for both SB1100 and SB2500 inverters. PV panels affected by shadow are marked in the software.

\section{TABLE I}

Meteorological data for Isparta, Turkey.

\begin{tabular}{c|c|c|c}
\hline \hline Date and time & $\begin{array}{c}\text { Sunshine } \\
\text { duration }[\mathrm{h}]\end{array}$ & $\begin{array}{c}\text { Temp. } \\
{\left[{ }^{\circ} \mathrm{C}\right]}\end{array}$ & $\begin{array}{c}\text { Radiation } \\
{\left[\mathrm{W} / \mathrm{m}^{2}\right]}\end{array}$ \\
\hline $01 / 05 / 201210: 00$ & 0.5 & 18.3 & 489.2167 \\
$01 / 05 / 201211: 00$ & 1 & 21.2 & 826.1383 \\
$01 / 05 / 201212: 00$ & 1 & 22.7 & 916.97 \\
$01 / 05 / 201213: 00$ & 0.9 & 24.9 & 923.9667 \\
$01 / 05 / 201214: 00$ & 1 & 25.4 & 920.0567 \\
$01 / 05 / 201215: 00$ & 1 & 25.7 & 818.5383 \\
$01 / 05 / 201216: 00$ & 1 & 25.7 & 678.175 \\
$01 / 05 / 201217: 00$ & 1 & 25.4 & 492.0783 \\
$01 / 05 / 201218: 00$ & 1 & 24.8 & 291.6533
\end{tabular}

Simulation can be started after genetic algorithm parameters have been determined. After optimization process is finished, the power of each PV panel produced during one day is shown in the software. In population form, new designs from genetic algorithm can be investigated in Table II. 
TABLE II by using 9 series and 2 parallel PV panels connection.

Population form data. If connection is made without optimization process, it produces a total power of $7434.8 \mathrm{~kW}$, however, it pro-

\begin{tabular}{c|c|c|c|c|c|c}
\hline \hline $\begin{array}{c}\text { Genera- } \\
\text { tion no. }\end{array}$ & $\begin{array}{c}\text { Individ. } \\
\text { count }\end{array}$ & $\begin{array}{c}\text { Gene } \\
\text { count }\end{array}$ & $\begin{array}{c}\text { Inverter } \\
\text { count }\end{array}$ & $\begin{array}{c}\text { Number } \\
\text { of shunt }\end{array}$ & $\begin{array}{c}\text { Number of } \\
\text { series PV }\end{array}$ & $\begin{array}{c}P \text { total } \\
{[\mathrm{kW}]}\end{array}$ \\
\hline 1 & 42 & 54 & 3 & 2 & 9 & 7624.684 \\
1 & 42 & 54 & 3 & 2 & 9 & 8004.435 \\
1 & 42 & 54 & 3 & 2 & 9 & 7814.559 \\
1 & 42 & 54 & 3 & 2 & 9 & 8194.31 \\
1 & 42 & 54 & 3 & 2 & 9 & 8194.31 \\
1 & 42 & 54 & 3 & 2 & 9 & 8194.31 \\
1 & 42 & 54 & 3 & 2 & 9 & 7814.559 \\
1 & 42 & 54 & 3 & 2 & 9 & 7814.559
\end{tabular}
duces the power of $8004.4 \mathrm{~kW}$ after optimization process. This situation provides optimization rate of $7.6 \%$. Information about optimization on SB1100 and SB2500 type inverters is shown in Table III.

TABLE III

Optimization results.

\begin{tabular}{c|c|c}
\hline \hline Inverter type & SB1100 & SB2500 \\
\hline Number of inverter & 3 & 1 \\
Number of PV panel & 54 & 42 \\
Parallel lines & 2 & 3 \\
Series PV & 9 & 14 \\
PV array power without GA [kW] & 7434.8 & 5765.6 \\
PV array power with GA $[\mathrm{kW}]$ & 8004.4 & 6342.0 \\
Efficiency & $7.60 \%$ & $9 \%$
\end{tabular}

The simulation using SB1100 type inverter contains

3 inverters and $54 \mathrm{PV}$ panels. Circuit design is made

Optimization process is performed for both, SB1100 and SB2500 type inverters. It is considered that all factors affecting PV panel performance and specifications in genetic algorithm are the same; so that system designs for different inverters can be investigated.

Efficiency

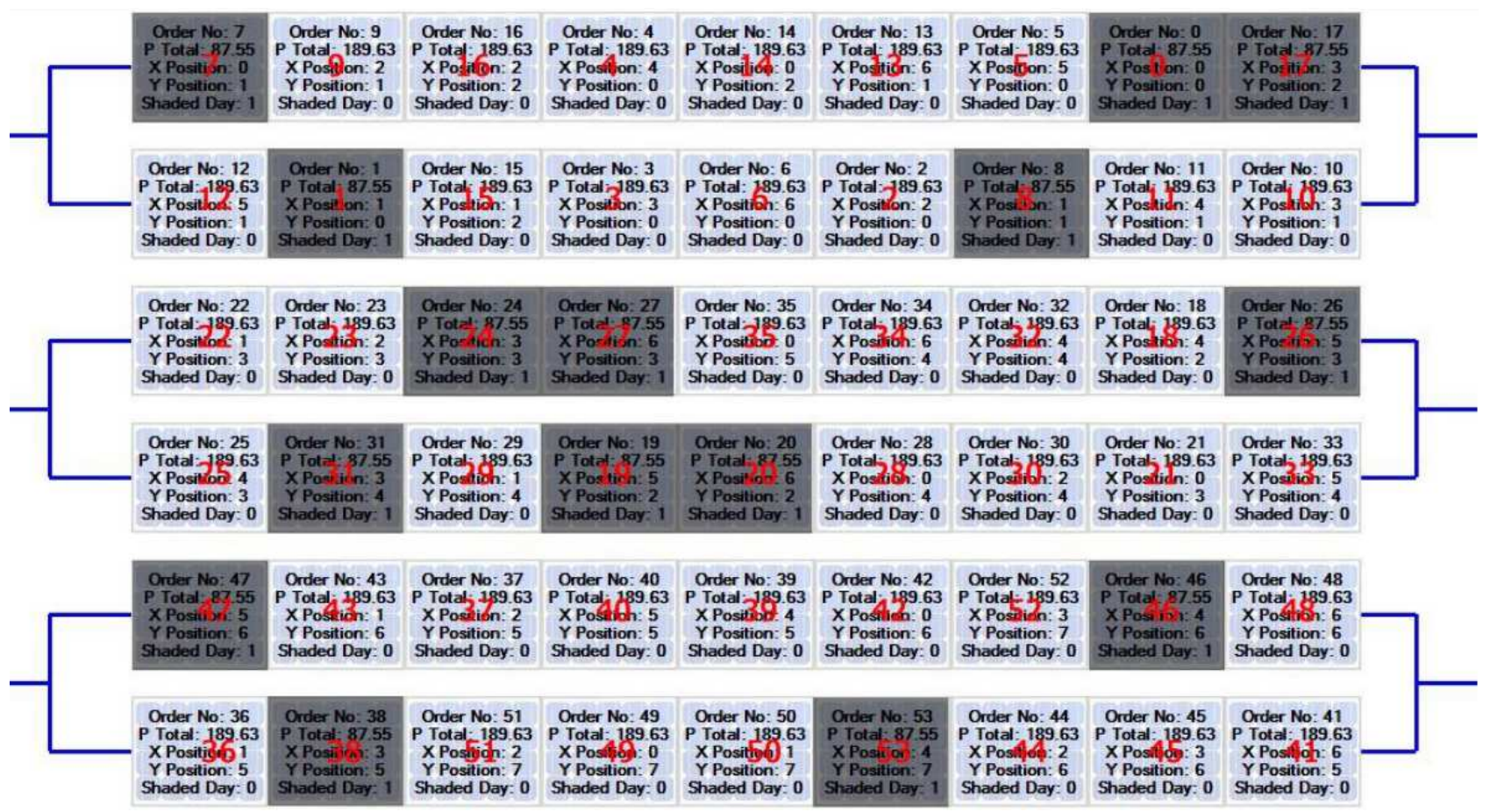

Fig. 3. Best individual solution for PV panel array with SB1100 inverter.

As a different case, the simulation of the optimization program was repeated with same parameters for different shaded panels. Shaded PV panels, marked in program, are given in Table IV. Depending on the inverter type, the optimization program provides optimization rate of $9.0 \%$ and $11.7 \%$. Information about optimization for SB1100 and SB2500 type inverters is shown in Table V.
Returning to the first shading case, the best PV panel array design using SB1100 model inverter, is shown in Fig. 3. After optimization process, efficiency of the PV array design is affected positively when number of shady panels is equal or similar in parallel lines. Besides there are differences in PV array designs depending on inverter choice. Thus the inverter must be analyzed before PV panel implementation. 
TABLE IV

Shaded PV panels on grid system.

\begin{tabular}{c|c|c|c|c|c|c|c}
\hline \hline Depth & L1 & L2 & L3 & L4 & L5 & L6 & L7 \\
\hline 1 & 1 & 1 & 0 & 0 & 0 & 1 & 1 \\
2 & 1 & 1 & 0 & 0 & 0 & 1 & 1 \\
3 & 0 & 0 & 1 & 1 & 0 & 1 & 1 \\
4 & 0 & 0 & 1 & 1 & 0 & 1 & 1 \\
5 & 0 & 0 & 0 & 0 & 0 & 0 & 0 \\
6 & 1 & 1 & 0 & 1 & 1 & 0 & 0 \\
7 & 1 & 1 & 0 & 1 & 1 & 0 & 0 \\
8 & 1 & 1 & 0 & 0 & 0 & 0 & 0
\end{tabular}

TABLE V

Optimization results of the shading case.

\begin{tabular}{c|c|c}
\hline \hline Inverter type & SB1100 & SB2500 \\
\hline PV array power without GA [kW] & 6295.5 & 4901.0 \\
PV array power with GA [kW] & 6865.1 & 5477.4 \\
Efficiency & $9.0 \%$ & $11.7 \%$
\end{tabular}

\section{Conclusions}

This study provides determination of the most efficient connection type and PV panel sequence before the PV panel implementation. Thus, implementation costs and feasibility of PV panel system can be analyzed. Besides, data affecting PV panel performance can be dynamically added to project and this opens wide usage areas in the future. Especially now, when renewable energy is very important, this project provides environmental and economical benefits.

\section{References}

[1] Yenilenebilir Enerji Genel Müdürlüğü (YEGM), 2014. Türkiye'de Güneş Enerjisi. Erişim Tarihi: 03.07.2014. www.eie.gov.tr/eie-web/turkce/YEK/ gunes/tgunes.html.

[2] M. Cetin, N. Egrican, Energy Policy 39, 7184 (2011).

[3] A. Chouder, S. Silvestre, J. Sol. Ener. Eng. 131, 024504 (2009).

[4] H. Tian, F. Mancilla-David, K. Ellis, E. Muljadi, P. Jenkins, Sol. Energy 95, 1 (2013).

[5] K. Ishaque, Z. Salam, Sol. Energy 85, 2217 (2011).

[6] R. Ramabadran, B. Mathur, Mod. Appl. Sci. 3, 1 (2009).

[7] R. Ramaprabha, Int. J. Electric. Robotic Electron. Commun. Eng. 8, 96 (2014).

[8] S.R. Potnuru, D. Pattabiraman, S.I. Ganesan, N. Chilakapati, Renew. Energy 78, 264 (2015).

[9] A. Chouder, S. Silvestre, N. Sadaoui, L. Rahmani, Simulation Modell. Pract. Theor. 20, 46 (2012).

[10] M. Seyedmahmoudian, S. Mekhilef, R. Rahmani, R. Yusof, Energies 6, 128 (2013).

[11] R. Ramabadran, B. Mathur, J. Sustain. Dev. 2, 85 (2009).

[12] E. Karatepe, M. Boztepe, M. Colak, Sol. Energy 81, 977 (2007).

[13] J. Li, Z. Peng, Optik 126, 5230 (2015).

[14] N.A. Khalil, R. Ahmed, A.M. Soliman, Microelectr. J. 46, 1060 (2015).

[15] H.-L. Liu, Appl. Acoust. 102, 71 (2016). 